\title{
Biblia e Ilustración en la crítica de la religiosidad barroca
}

\author{
Bible and Enlightenment \\ in the Baroque religiosity critique \\ Antonio Mestre Sanchis \\ Universidad de Valencia
}

CESXVIII, núm. 27 (2017), págs. 139-166 DOI: https://doi.org/10.17811/cesxviii.27.2017.139-166

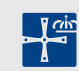




\title{
Resumen
}

Los católicos ilustrados se preocuparon por adaptar su manera de vivir el cristianismo a su forma cultural. De ahí que criticaran la excesiva religiosidad exterior, el sermón conceptista y que exigieran mayor rigor moral, al tiempo que pedían la libertad de leer la Biblia en lengua vulgar.

Palabras clave

Biblia, Ilustración, reforma eclesiástica, sermón, jansenismo, masonería.

\begin{abstract}
Enlightened Catholics were concerned with adapting their way of life to the cultural forms of their time. They criticized the excessive external religiosity and the conceptist preaching and demanded more moral rigor, at the same time that asked for freedom to read Holy Bible in vulgar language.
\end{abstract}

KEY WoRds

Baroque religiosity, Holy Bible, Conceptist Preaching, Jansenism, Masonry.

Recibido: 26 de junio de 2017. Aceptado: 11 de julio de 2017. 
Religiosidad y cultura

El cristianismo, con vocación universal y permanente, llega a los creyentes por medio de la palabra, expresada en una cultura concreta: griega, latina... Pero esa forma cultural no es permanente, sino mutable. En consecuencia, el cristianismo tiene que expresarse en consonancia con la cultura en que convive ${ }^{l}$.

Viene esta reflexión para comprender la actitud de algunos católicos ilustrados españoles del XVIII ante las formas exteriores y barrocas en que recibieron la religiosidad. No eran herejes, ni escépticos. En su mayoría eran católicos sinceros y buscaron una reforma respetuosa con la ortodoxia. Religiosos (Feijoo, Andrés...) o seglares (Mayans, Piquer, Jovellanos...), eran sinceros y buscaron eliminar deficiencias eclesiásticas y religiosas en busca de una mayor perfección, menos exterior y superficial en las formas y más profunda y personal. En el fondo - y en sus expresiones y actitud — disentían de las formas religiosas dominantes. Conste, desde el primer momento, que no voy a abordar el tema de la expulsión de los jesuitas, tema que, por sí solo, exige un capítulo, debido a las implicaciones políticas, con la permisividad o complacencia de obispos y religiosos. Ni estudiaré el regalismo, de cuyos criterios participaban la mayoría de los obispos, dentro de la oposición generalizada a la Curia Romana.

Porque el Concilio de Trento, además de condenar la teoría luterana de la justificación por la fe, y de consolidar la supremacía jurisdiccional del Papa, defendió la libertad humana, pues la naturaleza no es esencialmente corrupta. Esta defensa de la naturaleza, en contraste con el radicalismo luterano, propició una exaltación de las formas exteriores de la fe. Y, al mismo tiempo, ante el criterio luterano de la interpretación personal de la Sagrada Escritura, Roma prohibió en el artículo IV del Índice la lectura de la Biblia en lenguas vulgares. Prohibición que adoptó, y amplió con mayor rigor, la Inquisición española. Esta prohibición de leer la Escritura en la lengua del pueblo era lamentada por teólo-

1 Aunque analizado el tema desde otra perspectiva, resulta muy clarificador el trabajo de José Manuel SÁnchez Caro, «Biblia e ilustración: versiones castellanas de la Biblia en el siglo XVIII», Helmántica, 177 (2007), págs. 397-496. 
gos, que participaban del criterio erasmiano. En cambio, otros aceptaron la prohibición inquisitorial. En ese sentido. Melchor Cano consideraba que bastaba el sermón para el conocimiento de la Biblia, pues de esa manera se evitaban interpretaciones individuales erróneas, como había sucedido con los luteranos.

No hay duda de que hubo abusos en el desarrollo de estos aspectos. En el campo de las formas externas de la religiosidad, las procesiones y ceremonias pomposas llegaron a extremos insospechados: solemnidades universales, nacionales, locales, a la Virgen, a los santos..., promovidas por clero, cofradías y gremios. Y respecto al sermón, se convirtió en factor esencial. Dada la ausencia de medios de comunicación — ni revistas, ni periódicos—, el sermón se convirtió en un instrumento de difusión religiosa, cultural o política. En el XVIII hubo sermones políticos. En la Guerra de Sucesión, por supuesto, con argumentos religiosos utilizados por los partidarios de Felipe $\mathrm{V}$ y por los defensores del Archiduque Carlos. Lo curioso es que los dos bandos utilizaban idénticos argumentos. También hubo sermones políticos en la guerra contra la invasión napoleónica. Todos hablaron de cruzada religiosa. Más extraño es que un prestigioso predicador de la Corte, el P. Gallo, hablase en sus sermones de una «cruzada», cuando se trataba de una guerra dinástica suscitada por el Pacto de Familia entre España y Francia.

Ahora bien, el sermón barroco, culterano o conceptista, constituyó una verdadera tragedia. ¡Y eran tan frecuentes! No había fiesta o celebración religiosa que no fuera acompañada del tradicional sermón. No se trataba de las homilías dominicales que los párrocos más fervorosos predicaban a sus feligreses. Se conservan algunos sermones inéditos (Felipe Bertrán) ${ }^{2}$ y otros impresos (José Climent) ${ }^{3}$, sino de los sermones de fiestas, acompañados de toda la parafernalia posible y, en consecuencia, espectaculares. Se buscaba al orador más afamado que deseaba sobresalir con expresiones rebuscadas o conceptos incomprensibles para los fieles oyentes. Formalismo exterior y superficial, sermón fastuoso y conceptista. Son dos defectos de la religiosidad barroca de finales del XVII y principios del xVIII, y no eran los únicos, que los católicos ilustrados señalaban, y querían corregir.

2 Vicente León NaVarro, Luis de Granada y la tradición erasmista en Valencia. El siglo XVIII, Alicante, Instituto de Estudios Juan Gil-Albert / Diputación de Alicante, 1986.

3 Francesc Tort, El obispo de Barcelona, Joseph Climent $i$ Avinent (1706-1781). Contribución a la historia de la teología pastoral tarraconense en el siglo XVIII, Barcelona, Balmes, 1978. 
Los historiadores de la ciencia y de la cultura en general han señalado la importancia de los últimos años del siglo XVII en la evolución cultural española. Especial interés ha suscitado el año 1687, coincidiendo con la aparición de Philosophiae naturalis principia mathematica de Newton. Y que, entre nosotros, al margen de otros autores anteriores (Vicente Mut, José Zaragoza, Caramuel...), vendría marcado por la publicación en Madrid de la Carta filosófica médicochymica de Juan de Cabriada ${ }^{4}$, pregonando la necesidad de apertura a Europa y exigiendo la experiencia como única fuente de ciencia. Por cierto, las expresiones de Cabriada iban acompañadas de una notable actividad de científicos. El Ayuntamiento de Valencia enviaba ese mismo año al microscopista Crisóstomo Martínez a París, donde redactó un Atlas anatómico sobre el cuerpo humano, que alcanzó gran fama y que constituye, a juicio de López Piñero, la mayor aportación española del momento a la ciencia moderna ${ }^{5}$. Por lo demás, Juan Bautista Corachán realizó la primera adaptación del pensamiento de Descartes en la literatura española y dejó inédito un manuscrito, con un título muy expresivo: Methodus elaborandi componendique Telescopia et Microscopia, redactado, según Vicente Peset, a principios del siglo XVIII. Los límites de la actividad de los novatores resultan evidentes: ignoraban la obra científica de Newton.

Ahora bien, la apertura a Europa no fue solamente científica. También lo fue en el campo de la historia crítica y, en consecuencia, en aspectos religiosos. La obra de Michel Dubuis sobre las relaciones de la Congregación de Valladolid (a la que pertenecían el cardenal Sáenz de Aguirre y el P. Feijoo) con los benedictinos de San Mauro de París resulta reveladora ${ }^{6}$. Adquiere especial relieve la figura de Sáenz de Aguirre: profesor de teología escolástica en Salamanca, premiado por Roma con el cardenalato por su oposición a los cuatro artículos galicanos de Bossuet, trasladó su residencia a Roma. Y en la Ciudad Eterna se hizo visible su evolución en relación epistolar con los maurinos, y acabó su Collectio maxima Conciliorum Hispaniae et Novi Orbis (1693-1694). La obra, valiosa, también tiene sus deficiencias, como señalaba su secretario, y colaborador, Manuel Martí, en carta posterior al marqués de Mondéjar: Martí avisó

4 Juan de Cabriada, Carta filosofica medico-chymica en que se demuestra que de los tiempos y experiencias se han aprendido los Mejores Remedios contra las Enfermedades, Madrid, Lucas Antonio de Bedmar y Baldivia, 1687.

5 Crisóstomo Martínez, El Atlas anatómico de Crisóstomo Martínez, grabador i microscopista del siglo XVII, ed. de José María López Piñero, Valencia, Ayuntamiento de Valencia, 1964.

6 Michel Duburs, L'Espagne et Saint-Maure. La Congrégation de Valladolid dans le mouvement érudit entre 1670 et 1790, Paris, Université de Paris IV, 1982, 3 vols. [Thèse d'état inédita]. 
al cardenal de que los argumentos favorables a la tradición jacobea carecían de fuerza ${ }^{7}$, pero Aguirre siguió su criterio en favor de la venida de Santiago. Conviene señalar que en este aspecto todos los novatores (Mondéjar, Nicolás Antonio, y hasta los PP. Feijoo y Flórez) respetaban las tradiciones jacobeas.

Aparte de su relación con Nicolás Antonio, cuya Bibliotheca Hispana Vetus acabó de editar (1695-1696), Aguirre conoció los ambientes religiosos romanos, y pronto podía señalar su juicio sobre los llamados jansenistas. Los defensores de las 5 proposiciones eran poquísimos, los partidarios de un mayor rigor moral y defensores de la iglesia primitiva eran muchos, y los enemigos de los jesuitas eran un ejército. Conviene tener presente este juicio sobre el jansenismo, porque Manuel Martí, colaborador y secretario de Aguirre, presumía de ser amigo íntimo del cardenal Enrique Noris, considerado jansenista y condenado, como tal, por la Inquisición española en 1748, bajo la influencia del jesuita P. Rávago, confesor de Fernando VI. Asimismo, Martí mantuvo cordial relación con el círculo reformista napolitano, especialmente con Gravina, poco amigo de los jesuitas ${ }^{8}$.

Resulta innegable la influencia de los maurinos, con su actitud crítica en el campo de la historia, pero con evidente galicanismo en sus planteamientos eclesiástico-religiosos. Tampoco hay duda de que los autores galicanos, con evidentes matices religiosos, eran conocidos en España y concretamente en la Corte. En 1718 aparecía publicado en Madrid el Catecismo histórico del abate Claudio Fleury, traducido por Juan Interián de Ayala9. El traductor, catedrático de Salamanca y uno de los cofundadores de la Real Academia de la Lengua Española, dedicó su traducción al director de la docta Institución, el marqués de Villena. Fleury fue un autor muy conocido. Además de las numerosas ediciones del Catecismo histórico, también fue impreso Costumbres de los israelitas y cristianos, traducido por Martínez Pingarrón (1739) y reeditado por el obispo de Barcelona José Climent (1769), así como Obligaciones de los amos y de los criados (1741).

Y de Fleury a Bossuet, el más admirado. En la misma línea, Mayans aconsejaba a su amigo Juan Bautista Cabrera la lectura del obispo de Meaux, cuyas obras había ido adquiriendo con tenacidad hasta 24 tomitos. De cualquier forma, conviene tener en cuenta que no solo interesaban los aspectos políticos, sino también los religiosos:

\footnotetext{
7 Gregorio MaYans y Siscar, Epistolario III. Mayans y Martí, ed. de Antonio Mestre Sanchis, Valencia, Ayuntamiento de Oliva, 1973.

8 Sobre la importancia de la presencia de los españoles en Roma a finales del XVII, puede verse mi «Estudio preliminar» a MAYAnS y SISCAR, Epistolario III. Mayans y Martí, págs. IX-LXIV.

9 Claude Fleury, Catecismo histórico que contiene en compendio la Historia Sagrada y la Doctrina christiana, traducido en español por F. Juan Interián de Ayala, Zaragoza, s. l., s. a.
} 
El libro de Bossuet que yo he deseado mucho leer ha sido su Defensa de las cuatro proposiciones del clero galicano. Me gustan mucho los libros suyos intitulados: Instrucciones sobre los estados de oración, Diversos escritos o Memorias sobre el libro intitulado Explicación de las Máximas de los santos, Elevaciones a Dios sobre todos los misterios de la Religión Cristiana, Política sacada de las propias palabras de la Sagrada Escritura. Todas las obras de este autor me agradan mucho por ser tan sólidas. Pero más quisiera tener todas las de [Arias] Montano ${ }^{10}$.

En ese sentido escribirá con rotundidad: «Ha de saber V. S. que Arias Montano, don Antonio Agustín y Jacobo Benigno Bossuet son los tres escritores modernos que yo comparo a los más aventajados de la antigüedad en la perfección de saber las cosas». En esta línea reformista habría que añadir la influencia del italiano Luis Antonio Muratori, especialmente con sus dos obras clásicas: De superstitione vitanda y De ingeniorum moderatione, sin olvidar su crítica histórica.

\section{La herencia del humanismo español}

He buscado un texto en que aparezcan las dos líneas reformistas. Porque la influencia del galicanismo religioso no estuvo reñida con el interés por el conocimiento y admiración de los grandes escritores del XVI español. Y no deja de resultar sorprendente que son los mismos autores los que defienden el valor de ambas corrientes religiosas. Así, en Roma convivieron el cardenal Sáenz de Aguirre, Nicolás Antonio y un clérigo menos famoso, Manuel Martí, que colaboró en la edición de las obras de los dos grandes colosos, sin olvidar que se conserva una interesante correspondencia entre Interián de Ayala y Manuel Martí. Pues bien, por consejo de Martí, Mayans, con la lectura de la Bibliotheca hispana de Nicolás Antonio, descubrió la excepcional valía de los autores castellanos del XVI y manifestó con inesperada rapidez su sorpresa y admiración: Oración en alabanza de las elocuentísimas obras de don Diego Saavedra Fajardo (1725) y Oración que exhorta a seguir la verdadera idea elocuencia española (1727). Ahora bien, al hablar en la Oración sobre Saavedra Fajardo, don Gregorio citaba a los mejores autores que, a su juicio, habían escrito en la lengua castellana, pero entre los autores citados no estaba Fr. Luis de León. El P. Ayala, con quien mantenía correspondencia literaria y a quien había enviado un ejemplar de la Oración, le censuró amistosamente por no haber citado al gran poeta

10 G. Mayans a J. B. Cabrera, 16-IX-1741, Biblioteca del Archivo Hispano Mayansiano (Colegio Corpus Christi, Valencia, n. $\left.{ }^{\circ} 118\right)$. 
y autor de De los Nombres de Cristo. El joven catedrático de Código de Derecho contestó que conocía bien las obras de Fr. Luis, pero que, en adelante, gracias al recuerdo de Ayala lo citaría con elogio. Y así hizo con sinceridad a lo largo de toda su vida.

En estos dos ensayos aparecen con claridad los gustos literarios de Mayans, centrados preferentemente en los escritores del siglo XVI. Así, además de Cervantes, cita a Garcilaso de la Vega, Ambrosio de Morales, Hurtado de Mendoza, Saavedra... Pero también podemos leer elogios de autores con intencionalidad favorable a la lectura de la Escritura: A. Venegas, Fr. Luis de Granada, Fr. Luis de León... Porque, después de la advertencia de Ayala, el poeta agustino fue celebrado generosamente y, en muchos casos, unido a su coetáneo Fr. Luis de Granada. Valga este texto por todos. Después de los calurosos elogios a De los nombres de Cristo, por su propiedad de pensamiento, fuerza de razones, elección de autoridades, escribe:

La lástima es que las obras de este tan gran varón [Fr. Luis de León], de los venerables maestros [Fr. Luis de] Granada y [Juan de] Ávila, y de otros pocos (pues semejantes a ellos en muchos siglos hay pocos) o no suelen leerse o, si por ventura se leen, no se suele conocer lo mejor que tienen ${ }^{11}$.

Después de conocer la influencia de los autores galicanos, así como el descubrimiento y valoración de los humanistas cristianos españoles del XVI, los críticos de la religiosidad barroca, tenían que buscar reformas en tres aspectos fundamentales: las frecuentes supersticiones, el sermón conceptista y la prohibición de la lectura de sagrada Escritura en la lengua del pueblo.

\section{Las supersticiones de la religiosidad popular}

Dada la convicción de los reformistas de que luchaban contra la ignorancia y la superstición, resulta lógico y coherente que la crítica contra la superstición sea generalizada a lo largo del siglo: Feijoo, Mayans, Cañuelo, Meléndez Valdés, Jovellanos... Me limito a señalar unos textos de Feijoo, Mayans y Jovellanos, de principio a final de siglo, autores de cuya sinceridad religiosa no hay la menor duda.

Probablemente sea Feijoo el autor que con más habilidad combatió la superstición. Y supo utilizar el género literario más adecuado: el ensayo que sus-

11 Gregorio MaYans y Siscar, Oración que exhorta..., Obras completas II, ed. de Antonio Mestre Sanchis, Valencia, Ayuntamiento de Oliva, 1984, pág. 572. 
citaba interés y comprensión. Además, el benedictino afronta la crítica de la superstición desde múltiples vertientes. Por supuesto en los aspectos relativos a la meteorología que los campesinos confiaban en imágenes o ceremonias milagrosas $^{12}$, pero también frente a recuerdos heredados del mundo pagano o prácticas centradas en días y animales concretos. En este último caso, resulta curiosa e ilustrativa su crítica del toro que, llevado a la iglesia el día de S. Marcos, se presentaba dócil y era recibido por el párroco con ornamentos litúrgicos y era adornado con guirnaldas y flores. Sorprende que Feijoo tenga que dedicar al asunto un discurso del Teatro crítico (TC, VII, 8), y que vuelva al mismo tema en sus Cartas eruditas (CE, I, 43). El mismo Feijoo expresaba su criterio: «La piedad que la Iglesia pide, la que promueve en sus hijos, la que caracteriza a los buenos cristianos, es aquella que se junta y hermana con la verdad» (CE, I, 43, 5).

Otras veces la superstición contenía aspectos más doctrinales. Mayans censuraba el hecho de que una imagen de la Virgen recibiera el calificativo de «Virgen del Incendio» (por haberse salvado en un incendio, sin que tuviera que suponer un milagro) en vez de una adjudicación verdadera: podía inducir a superstición. Aunque la censura más sorprendente fue la aplicada al calificativo de Divina Pastora. Porque, según explicaba, el único Pastor es Cristo, y la Virgen, aun con tan alta santidad (Mayans creía en la Inmaculada Concepción), era persona humana y nunca podía ser llamada divina ${ }^{13}$.

Finalmente, unas palabras de Jovellanos sobre la imagen del Cristo de Burgos. Su reflexión parece indicar la pugna entre diversas órdenes religiosas por conseguir mayor presencia de los fieles y las limosnas consiguientes ${ }^{14}$.

Resulta imposible hablar de las supersticiones, sin aludir con la mayor brevedad a la lucha contra las tradiciones eclesiásticas. Los falsos cronicones o las láminas del Sacro Monte de Granada fueron rechazados con energía por la mayoría de los historiadores. El mejor síntoma de la lucha contra las falsas tradiciones eclesiásticas fue la publicación de la Censura de historias fabulosas de Nicolás Antonio (1742), gracias al esfuerzo de G. Mayans. Pero había tradiciones nacionales sobre el origen del cristianismo español: venida de Santiago,

12 Armando Alberola Romá, «Agricultura, clima y superstición en la España del siglo XVIII: algunas reflexiones del padre Feijoo», en Inmaculada Urzainqui y Rodrigo Olay Valdés (eds), Con la razón y la experiencia. Feijoo 250 años después, Oviedo, Instituto Feijoo de Estudios del Siglo XVIII / Ayuntamiento de Oviedo / Ediciones Trea, 2016, págs. 21-42. En el mismo volumen hay otras aportaciones sobre la actitud de Feijoo contra la superstición.

13 Mayans a José Nebot, 6-II-1749, en Antonio Mestre SAnCHIS, «Religión y cultura en el siglo XVIII», en Ricardo García-Villoslada (dir.), Historia de la Iglesia en España, Madrid, BAC, 1979, vol. IV, págs. 601-602.

14 Gaspar Melchor de Jovellanos, Obras Completas, tomo VII, Diario, 2. ${ }^{\circ}$, edición de María Teresa Caso Machicado y Javier González Santos, Oviedo, Instituto Feijoo de Estudios del Siglo XVIII / Ayuntamiento de Gijón, 1999, págs. 174-182 (24-IV-1795). 
aparición de la Virgen en Zaragoza, los Varones Apostólicos, que dividieron a los historiadores. Así, Feijoo y Flórez las defendieron; también Ferreras defendía la venida de Santiago como su maestro Mondéjar, aunque censuró la tradición de la Virgen del Pilar, trabajo prohibido por el Santo Oficio. En cambio, Martí, el deán de Alicante, las rechazó de principio en correspondencia privada. Y Mayans, que no se atrevió a censurarlas en público, se permitió negar el valor histórico de la tradición de la venida de Santiago en documentadísima carta al nuncio del Papa en Madrid (Monseñor Enrique Enríquez) y alabó a los extranjeros que la rechazaban ${ }^{15}$.

\section{La lucha contra el sermón barroco}

Resulta clamorosa la actitud crítica generalizada contra el sermón barroco, conceptista y culterano. Los testimonios podrían multiplicarse. Tanto religiosos (Martí, Feijoo, Isla...) como seglares (Mayans, Bolifón, Cañuelo, Jovellanos...) claman contra el abuso de los sermones, que no predican la palabra de Dios, sino que exponen conceptos abstrusos o imágenes estrambóticas, con la finalidad de demostrar ingenio y sorprender al oyente. Feijoo en el «Discurso sobre las glorias de España» (TC, IV, 13-14) lamentaba el estado de la predicación en España, pero confesaba sin reparo que no se atrevía a enfrentarse con la oposición que suscitaría. Confesaba que él mismo practicaba el modo ordinario de predicar, que no le gustaba, pero animaba a los más generosos a reformarlo:

Dada la dificultad de predicar con primor, serán pocos los que lo hagan, pero aquellos pocos harán un gran fruto, y a los demás, por mí, déjeseles libertad para seguir el ripio de sus puntos y contrapuntos, sus piques y repiques, sus preguntas, sus reparos y soluciones, sus mases, sus porqués, sus vueltas y revueltas... (TC, IV, 14, § XIV, 36).

Estas palabras del benedictino parecieron una cobardía a Mayans, como expresaba el mismo erudito a Feijoo en carta de 18-II-1733, con estas palabras: «quisiera que V. Rma. destinase a este asunto un discurso entero, en arrepentimiento de lo que imprimió en el núm. 36, del discurso 14 del tomo 4 de su Teatro critico, donde la cobardía de V. Rma. me pareció muy ajena de su

15 Sobre la lucha por introducir la historia crítica, Antonio Mestre Sanchis, Historia, fueros y actitudes políticas. Mayans y la historiografía del XVIII, Valencia, Ayuntamiento de Oliva, 1970. 
gran espíritu» ${ }^{16}$. Por cierto, Feijoo no aludió en su respuesta a esta invitación del erudito.

Ahora bien, en esa misma carta, el erudito anunciaba al benedictino su intención de dedicar un ensayo a corregir los abusos tan frecuentes en los sermones del momento. «Estoy acabando de escribir tres diálogos, en que doy una llenísima idea del orador cristiano, a fin de combatir fuertemente el vulgar modo de predicar; y que solo se predique la palabra de Dios, y como se debe. He tomado esta empresa muy de veras». De hecho, las críticas contra el sermón conceptista eran generales, y clamor general el deseo de su reforma. Así, el deán Martí, al conocer la intención de Mayans de redactar El orador cristiano, comentaba que era una de las cosas de que más urgente reforma necesitaba España ${ }^{17}$. En el mismo sentido se pronuncia Felipe Bolifón, italiano al servicio de Felipe V como superintendente en Alicante, y amigo de Martí: celebrando la obra de Mayans, narra algunos abusos clamorosos de sermones a los que asistió ${ }^{18}$.

En esas circunstancias publicó Mayans El orador cristiano (1733). El erudito, en forma dialogada, censuraba el sermón conceptista, y, proponiendo una pedagogía, que debía impartirse en academias, presentaba la necesidad del sermón basado en la sagrada Escritura, Santos Padres y Concilios. Y los modelos presentados eran los humanistas españoles del XVI, especialmente dos grandes figuras: Juan de Ávila y Fr. Luis de Granada. Probablemente Mayans esperaba mayor difusión de una obra valiosa y estimada en determinados ámbitos. Recibió felicitaciones y también críticas. Bien acogido en amplios círculos eclesiásticos y seglares, como era presumible, también recibió ataques, como presumía el autor, por haber metido la hoz en mies ajena un jurista dedicado a la reforma de la iglesia. Conviene aludir a la buena acogida por parte de los canónigos de la catedral de Valencia, que posteriormente ocuparon altos cargos en la jerarquía con amplia influencia.

Aunque es posible que el método irónico, utilizado por el P. Isla en su Fr. Gerundio de Campazas (1758), tuviera más influencia práctica. Últimamente, J. Jurado ha demostrado que muchos de los ejemplos citados por el jesuita correspondían a la realidad ${ }^{19}$. Pues bien, ese juicio ya lo hicieron y constataron los coetáneos. Orobio Bazterra, secretario de la Suprema, escribía a su amigo Mayans unas palabras reveladoras:

\footnotetext{
16 Mayans a Feijoo, 18-II-1733, en Antonio Mestre SAnchis, «Correspondencia Feijoo-Mayans, en el Colegio del Patriarca», El mundo intelectual de Mayans, Valencia, Ayuntamiento de Oliva, 1978, pág. 195.

17 Todas las citas sobre Manuel Martí, el deán de Alicante, en MaYans y SISCAR, Epistolario III. Mayans y Martí.

18 Mestre Sanchis, El mundo intelectual de Mayans, págs. 273-329.

19 José JuRado, «Introducción», en Jose Francisco de IsLA, Historia del famoso predicador Fray Gerundio de Campazas, ed. de José Jurado, Madrid, Gredos, 1992, págs. 7-69.
} 
Vm. ha pensado que el autor de Fray Gerundio finge un blasfemo, para afear y disuadir la blasfemia etc. No es así. Nada finge el autor ni dice que no esté escrito con letras de molde en algún sermón impreso o que, a lo menos, no se haya predicado poco ha, y le hayan oído todos o muchos de los que viven. Por ejemplo, el Sermón de las ánimas, que empezó con las palabras: Fuego, fuego, etc., fue el que predicó el P. Valle Zorraquín, predicador del Convento del Rosario de esta Corte, no ha mucho tiempo. Y así algunos curiosos tienen el libro de Fray Gerundio con nota de los sujetos de quienes habla el libro. Sería una cosa buena prohibir todos los Sermonarios gerundios, el libro de Fray Gerundio, y todos los papeles anónimos que han salido y saldrán contra él ${ }^{20}$.

Esa noticia demuestra el interés, más o menos morboso, por conocer a los predicadores gerundianos, y, con la máxima probabilidad, el deseo de algunos predicadores de evitar este rechazo. De cualquier forma, los proyectos reformistas, con una exposición más pedagógica, también continuaron. En este sentido, dos obispos, conocidos como buenos oradores y en relación con Mayans, publicaron sus Pastorales, exigiendo del clero de sus diócesis una preparación seria antes de predicar, centrada en la exposición de la palabra de Dios. Felipe Bertrán publicó una de sus primeras Pastorales centrada en la mejoría de los sermones de sus sacerdotes (y que envió a don Gregorio); y José Climent, obispo de Barcelona, reeditó la Retórica de Fr. Luis de Granada, como modelo y ejemplo de predicadores, y un grato recuerdo a la labor del erudito. Por lo demás, estos obispos han merecido una digna valoración del historiador francés Joël Saugnieux, en su libro Les jansénistes et le renouveau de la predication dans l'Espagne de la seconde moité du XVIII siècle (Lyon, 1976).

Eso no quiere decir que con las burlas del P. Isla y las Pastorales de los obispos se lograra una reforma completa del sermón barroco. A juicio de los historiadores, los sermones españoles mejoraron a finales de siglo. De hecho, fueron numerosos los libros que vieron la luz pública en el intento de elevar el nivel de los predicadores españoles. Y los hubo desde todas las perspectivas. El P. Antonio Codorniu, en El predicador evangélico. Breve método de predicar la palabra de Dios con arte y espíritu (1740) con ejemplos de sermones de los padres jesuitas; y tantos otros: Antonio de Capmany, José de Muruzábal, L. Soler de Cornellá, Pedro Antonio Sánchez, Francisco Gregorio de Salas... Sin embargo, hubo también quejas, más o menos oportunas, y, también críticos apasionados

20 A. Orobio Bazterra a G. Mayans, 8-IV-1758, en Gregorio MaYans y SISCAR, Epistolario XXII. Los hermanos Mayans y los inquisidores, ed. de Amparo Alemany Peiró, Valencia, Ayuntamiento de Oliva, 2007, vol. II, pág. 425 . 
del Orador cristiano de Mayans, como Fr. Nicolás de Aquino. Porque ese es un ideal muy difícil: exponer la palabra de Dios de la mejor forma, para que pueda ilustrar, y al mismo tiempo mover a la conversión. Ideal difícil de adquirir para los mejor dotados y casi imposible para el orador mediano de formación intelectual y teológica poco profunda ${ }^{21}$. En algunos autores la crítica se extendía a los sermones de misiones apostólicas, que constituyó un género aparte, y ha servido para modernos estudios sociológicos, tanto en Europa como en España ${ }^{22}$.

\section{La lucha por la lectura de la Biblia en la lengua del pueblo}

Si difícil era la lucha contra el sermón barroco y conceptista, mayor era la dificultad para enfrentarse a la prohibición de la lectura de la sagrada Escritura en la lengua hablada por los españoles. Aparte de la prohibición del apartado IV del Índice de Roma, estaba la mayor rigidez de la prohibición inquisitorial española, sobre todo porque ejercía un poder inmediato y ejecutivo. Hubo teólogos en España, como Fr. Luis de León, que lamentaban la prohibición inquisitorial, razón que alegaba para suplir esa deficiencia con la redacción de Los Nombres de Cristo. En cambio, otros teólogos no eran favorables a permitir la lectura del texto sagrado, y las prohibiciones inquisitoriales fueron aumentando en rigor: decreto sobre Biblias (1551), Índice del Inquisidor Valdés (1559) y finalmente la regla quinta del Índice del Inquisidor Quiroga (1583), que daba las normas más restrictivas. En esa línea iba el criterio de Melchor Cano: para evitar las desviaciones doctrinales ocurridas en Alemania, por leer la Escritura e interpretarla con libertad, bastaba la predicación del sacerdote para que los fieles, ignorantes del latín, pudieran conocer la palabra revelada. En esas circunstancias, era difícil solicitar la posibilidad de leer la sagrada Escritura en la lengua del pueblo.

Es bien sabido que, a pesar de la prohibición del Índice romano, no todas las naciones cumplieron con rigor la norma del Papado. Esta falta de cumplimiento de la prohibición se hizo muy visible en Francia, especialmente por la reserva del galicanismo y, sobre todo, por la resistencia de los jansenistas. En 1672 aparecía el Nouveau Testament de Mons, y años después la Gran Biblia en francés, gracias al interés y trabajo de Sacy (1696). Los jansenistas tomaron como bandera la lectura de la Biblia en francés. De ahí, la condena de la

21 Una síntesis clarificadora del problema de la reforma del sermón, en Teófanes EGIDo, «Religión», en Francisco Aguilar Piñal (ed.), Historia literaria de España en el siglo XVIII, Madrid, Trotta / CSIC, 1996, págs. 761-786.

22 Un buen estudio sobre el tema en Francisco L. Rico Callado, Misiones populares en España entre el Barroco y la Ilustración, Valencia, Institució Alfons el Magnànim, 2006. 
proposición 80 de Quesnel: Lectio Sacrae Scripturae est pro omnibus, en la Bula Unigenitus.

Pues bien, en 1718 Ayala publicaba la traducción castellana del Catecismo histórico de Claudio Fleury. Y en una nota marginal escribió estas palabras: «El autor, como francés, habla de su país, en donde son permitidas y frecuentes las traducciones de la Escritura; pero la doctrina se puede aplicar en otras partes, aun a los que saben precisamente algo de latín». Era una evidente invitación a aplicar la práctica francesa en otros países, entre ellos España.

La nota de Ayala no pasó desapercibida y tuvo críticos y defensores. Hay una concatenación innegable. Porque en septiembre de 1727, Mayans visitó Madrid y pudo leer en la biblioteca del marqués de Villena la traducción del Catecismo histórico, que reeditó al año siguiente. Dada la relación del erudito con su paisano Tomás Navarro, pavorde y catedrático de Teología suareciana en la Universidad de Valencia, se comprende con facilidad que el 2 de diciembre, el pavorde escribiera una carta censurando las palabras de Ayala. Carta que, trasmitida por don Gregorio a Ayala provocó una bella respuesta del traductor: «Satisfacción modesta, y aun humilde, a unos reparos, o a unos escrúpulos, que han opuesto contra la primera parte del Catecismo histórico y contra su traductor ${ }^{23}$. Ayala sabía muy bien las razones de su censor: el decreto de Trento, el Índice inquisitorial español y la Bula Unigenitus. Y supo defenderse con habilidad: la misa católica, además de un acto de culto, entraña una función doctrinal con lectura de textos bíblicos; es un hecho innegable que en Francia es frecuente que la jerarquía permita la lectura de la Biblia en francés, y, por supuesto, Ayala no es jansenista, sino buen tomista, como ha demostrado en la cátedra de la Universidad de Salamanca. Además, dado el carácter del opositor, catedrático de teología antitomista, utiliza en defensa de la lectura de la Escritura autores de la Compañía de Jesús. Finalmente, empleando unas palabras de Fr. Luis de León, recuerda que, en los primeros siglos del cristianismo, todos los fieles podían leer en su lengua la sagrada Escritura, los latinos en latín y los griegos en su lengua materna ${ }^{24}$.

Claro que no todos los partidarios de la lectura de la Biblia en la lengua de pueblo tenían el apoyo institucional de Ayala, cofundador de la Real Academia Española, favorecido tanto del marqués de Villena como de su orden religiosa.

23 Antonio Mestre SAnChis, «Las primeras defensas de la lectura de la Biblia en lengua vernácula en el siglo XVIII», en VV. AA., Studia historica et philologica in honorem M. Batllori. Roma, Anexos de Pliegos de Cordel / Instituto Español de Cultura, 1984, págs. 731-741.

24 En el fondo mayansiano del Colegio del Patriarca, puede leerse una copia de esta apología, de letra del minutante de Ayala. El texto completo en Mestre Sanchis, «Las primeras defensas de la lectura de la Biblia en lengua vernácula en el siglo XVIII», págs. 735-739. 
Así, defensores como Mayans, que, habiendo leído el Catecismo histórico en la biblioteca del marqués de Villena, reeditó la obra de Fleury con elogios del autor. Y, al redactar el prólogo de la Filosofía de Juan Bautista Berní, en castellano, aprovechó la ocasión para indicar que todos los países tienen la filosofía en la lengua del pueblo y los hebreos tenían la suya en su lengua hebrea.

De cualquier forma, la idea de traducir al castellano la sagrada Escritura y permitir que el texto pudiera ser leído por los fieles en su propia lengua fue extendiéndose. En general, esa extensión se produjo por medio de tres líneas: la publicación de obras de autores que defendían las traducciones de la Biblia, la necesidad de los predicadores de citar textos de la sagrada Escritura y la actitud de los Papas.

Mayans había descubierto el valor de las obras de Arias Montano durante sus años de bibliotecario real, pues no las había leído antes por consejo de sus amigos jesuitas de que no leyera las obras del director de la Políglota de Amberes (porque era hebraísta). Así, después de editar la Lección cristiana, según la traducción del Dictatum christianum por Pedro de Valencia (1739), la difundió entre sus allegados. Y, años después, las ediciones de Fr. Luis de León. Y, cuando encontró la traducción de Arias del Cantar de los cantares, propició una copia a Pérez Bayer y al arzobispo Andrés Mayoral ${ }^{25}$.

En estricto paralelo cronológico, aparecen las preocupaciones de los predicadores. Siguiendo el consejo de El orador cristiano, los predicadores valencianos querían ofrecer a los fieles las palabras de la Biblia. Pero, aunque resulte extraño, no podían citar los textos bíblicos en castellano, sino en latín. Ante esa contradicción, deseaban encontrar una Biblia traducida en castellano. Y, dado que no existía ninguna versión castellana hecha por autores católicos, Mayans les aconseja que compren una Biblia traducida por los protestantes del XvI, Casiodoro de la Reina o de Cipriano de Valera: «Es cierto que Casiodoro de la Reina tradujo la Biblia en español y que lo que hizo después Cipriano de Valera fue añadir unas notas a la margen. Yo hice este cotejo. De Reina no tengo noticias especiales, ni de Valera ${ }^{26}$. Estas palabras de 1751 a José Cevallos, el futuro rector de la Universidad de Sevilla, vienen a confirmar que el erudito poseía la traducción de los protestantes españoles y explican a la perfección sus consejos. Las cartas estaban dirigidas a sus amigos, Asensio Sales, futuro obispo de Barcelona, y a su íntimo Juan B. Cabrera, beneficiado de la catedral, animándolos a comprar la Biblia traducida por los protestantes españoles.

25 Antonio Mestre Sanchis, «Estudio introductorio», en Gregorio MaYans y Siscar, Epistolario VI. Mayans y Pérez Bayer, ed. de Antonio Mestre Sanchis, Valencia, Ayuntamiento de Oliva, 1995, págs. VII-LXXIX.

26 G. Mayans a J. Cevallos, 3-X-1751, en Antonio Mestre Sanchis, Correspondencia de los ilustrados andaluces, Sevilla, Consejería de Cultura, 1992, pág. 174. 
Años después, aumentaron las ediciones de autores españoles defensores de las traducciones de la Escritura en castellano. Pero entonces ya tenían un apoyo en la postura del Papado. Porque, en 1757, Benedicto XIV permitía la edición de traducciones de la Biblia a las lenguas del pueblo, siempre que fueran acompañadas de comentarios de los Santos Padres o de autores católicos que explicaran los pasajes más difíciles.

En ese contexto se publicó en Valencia De los nombres de Cristo de Fr. Luis de León (1770). Interesa señalar el amplio prólogo de Vicente Blasco, monje de la orden militar de Montesa, futuro canónigo de la metropolitana, Rector perpetuo de la Universidad de Valencia y autor de un Plan de estudios (1787), muy celebrado por los ilustrados. Blasco era plenamente consciente de los problemas de su tiempo. Y, en paralelismo con el siglo XVI, en que ya estaba prohibida la lectura de la Escritura en la lengua vernácula, señala cómo un autor como Fr. Luis redactó De los nombres de Cristo para suplir esa carencia. En cambio, en el XVIII, los libros predominantes eran los de autores frívolos o anticristianos. Sin embargo, Blasco — que no citaba la Bula de Benedicto XIV, pues continuaba la prohibición inquisitorial - citaba una serie de traducciones italianas de los $\mathrm{He}$ chos de los Apóstoles (1747) de los Salmos y una Concordia evangélica traducida a la letra del texto de los evangelistas ${ }^{27}$.

Porque los españoles también miraban a Italia, aunque no fueran los documentos papales. Muratori publicaba en 1747 Della regolata divozione, que incluía la traducción al italiano de los textos bíblicos de la misa del domingo quinto después de la Epifanía. El libro de Muratori fue traducido al castellano en 1763 por Miguel Pérez Pastor. Pero había diferencias: el traductor suprimió la indicación de Muratori de que debían desminuirse algunas de las numerosas fiestas religiosas $\mathrm{Y}$, sobre todo, eliminó la traducción de los textos bíblicos de la misa. No hay duda de que detrás de la decisión del traductor está el temor al Santo Oficio. Así, escribe como justificación:

La verdad es que las cuestiones cuya noticia se ha omitido turbaron en algún modo la paz eclesiástica de la Italia y que en España no se han tratado, que yo sepa, sino especulativamente entre los doctos. Por eso me pareció razonable no ponerlas en la noticia de todos, con el justo recelo de que se pudiese suscitar entre nosotros las mismas controversias, sin excitar la devoción ${ }^{28}$.

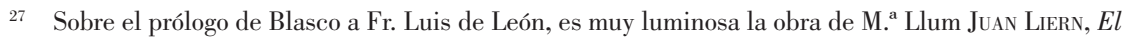
rector Vicente Blasco García (1735-1813). De la Ilustración al liberalismo, Valencia (en prensa).

${ }_{28}$ Ludovico A. Muratori, La devoción arreglada del cristiano, traducida, la publica el Dr. D. Miguel Pérez Pastor, Madrid, Joaquín Ibarra, 1763, págs. 11-12.
} 
Pero, a juzgar por la correspondencia personal, también había intelectuales que no gustaban de que los textos bíblicos fueron leídos por los fieles que desconocían el latín. He aquí unas palabras de Mayans al obispo de Barcelona Asensio Sales: «He sabido que Flórez hizo fuerte oposición para que no saliese entera la Devoción regulada de Muratori. Fraile había de ser el que sostuviese la superstición frailesca ${ }^{29}$. Conviene señalar las divergencias.

Ahora bien, los defensores de la conveniencia de la traducción de la Escritura continuaron en su campaña. Y, a la edición de De los nombres de Cristo de Fr. Luis de León por parte de Vicente Blasco, siguió el P. Diego González con la de la Exposición del libro de Job (1779). Pero en este caso sin temor alguno. Antes bien, quiso señalar que el decreto de Benedicto XIV estaba en plena coincidencia con las ideas y bellas palabras de Fr. Luis de León. Y textos como los del Libro de Job son «utilísimos sin duda a toda clase de gentes y por lo mismo aplaudidos sobremanera por todos los prudentes que saben estimarlos». Además de citar el Breve de Benedicto XIV, se vale de la carta de Pío VI a Antonio Martini, futuro arzobispo de Florencia, felicitándole por su traducción de la Biblia. El P. González cita las palabras latinas de Pío VI, cuyo sentido coincide plenamente con el espíritu de Fr. Luis de León.

Eran las circunstancias propicias para modificar la actitud del Santo Oficio. Así, el Inquisidor General, Felipe Bertrán, concedía libertad de lectura de la sagrada Escritura en lengua vernácula. El decreto quería justificar las razones de la prohibición anterior, pero también confesaba que fue en España «con más extensión que la que comprende la regla cuarta del Índice del Concilio [de Trento] $»^{30}$. Ahora bien, habiendo cesado las causas de la prohibición y vista la utilidad que puede seguirse a los fieles, gracias a la instrucción que recibirían con la lectura de la Biblia, el Santo Oficio sigue las directrices de Roma: la declaración de la Sagrada Congregación en tiempo de Benedicto XIV (1757) y la carta de Pío VI alabando la traducción al italiano de Antonio Martini ${ }^{31}$.

Bertrán completaba la línea de sus compañeros valencianos: Mayans, Blasco... Pero no hay duda de que encontró apoyo y favor en el entorno de los monarcas. Así, el P. Felipe Scío de San Miguel, preceptor de las infantas, confiesa que Carlos III le había encargado la traducción de la Biblia al castellano en 1780.

\footnotetext{
29 Mayans a Sales, 2-IV-1764. Texto en Antonio Mestre Sanchis, Influjo europeo y herencia hispánica. Mayans y la ilustración valenciana, Valencia, Ayuntamiento de Oliva, 1987, pág. 228.

30 Las palabras concretas del decreto inquisitorial pueden leerse en GARcía-VILlosLada (dir.), Historia de la Iglesia en España, vol. IV, pág. 667.

31 El mejor estudio sobre Felipe Bertrán es el de León Navarro, Luis de Granada y la tradición erasmista en Valencia. El siglo XVIII. El autor tiene en prensa, de próxima aparición, un estudio profundizando en la persona y obra de Bertrán.
} 
Y encontró la mejor acogida en sus compañeros escolapios de Valencia, que prepararon la edición del Nuevo Testamento en 1790, continuada en años sucesivos hasta finalizar la traducción completa. Pero la resistencia de algunos autores a la lectura de la Biblia por parte de los fieles en su propia lengua continuó.

Ahora bien, los partidarios de la libertad de la lectura adquirieron mayor fuerza y energía. El favor del Santo Oficio explica la reacción de Joaquín Lorenzo Villanueva, hombre de confianza y protegido del Inquisidor Bertrán. Interesa constatar un hecho. En De la lección de la Sagrada Escritura en lenguas vulgares (1791), la apología del decreto inquisitorial favorable a la libre lectura de la Biblia va unida al uso que hace de los autores españoles del siglo XVI, que defendían esa libertad: Alexio Venegas, Fr. Luis de Granada, san Juan de Ávila, Fr. Luis de León, Fr. Luis de la Fuente, Francisco Ruiz, López de Montoya, Bartolomé Carranza, Antonio Porras, Felipe Meneses. Es decir, junto a los espirituales, aparecen los erasmistas, que Villanueva veía justificados en el nuevo decreto inquisitorial favorable a la libertad de lectura de la Sagrada Escritura.

\section{De las escuelas teológicas al jansenismo}

La palabra jansenismo ha sido polémica desde el primer momento Aparecido el jansenismo como consecuencia extrema de la polémica De auxiliis, entraña tres aspectos en íntima conexión: un contenido doctrinal, un aspecto moral y un envolvente político. Si bien, no adquieren los tres idéntica relevancia a lo largo de su evolución. El aspecto doctrinal del Augustinus de Jansenio alcanzó, en el primer momento, un evidente predominio, como quedó demostrado por las Bulas In Eminenti y, sobre todo, en la posterior Cum occasione de Inocencio X en 1753, con la condena de las 5 proposiciones.

Ahora bien, solucionado el carácter dogmático, aunque con protestas de los defensores del Augustinus, que negaban defender alguna de las 5 de las proposiciones condenadas, adquirió fuerza el carácter moral con Port-Royal y las Provinciales de Pascal, con un fuerte rigorismo y un ataque al probabilismo y a los jesuitas. Y, finalmente, la condena de Quesnel en la Bula Unigenitus de Clemente XI (1713) con la reacción de los Parlamentos franceses, el jansenismo tomó un carácter político.

Isaac Vázquez ha estudiado ${ }^{32}$ la aportación de los teólogos tomistas-agustinianos en la evolución doctrinal después de la polémica De auxiliis, y también

32 Isaac VÁzQuez JaNeiro, «Las controversias doctrinales postridentinas hasta finales del siglo XVII», en Ricardo García-Villoslada (dir.), Historia de la Iglesia en España, vol. IV, págs. 429-455. 
la aportación de los jesuitas a las propuestas antijansenistas de Roma, así como la participación en las polémicas posteriores, con Tarsicio González, prepósito de la Compañía. Pero ni él, ni otros historiadores han podido encontrar la obra de Rosende, el único supuesto jansenista doctrinal español, prohibido por la Inquisición, que procuró que desaparecieran los ejemplares. Solo algún historiador francés ha insinuado la posibilidad — pero confiesa que no pasa de posibilidad — de que hubiera una corriente jansenista subterránea y oculta. Eliminado, pues, en España el jansenismo doctrinal, las manifestaciones entre nosotros tomaron carácter moral y político. Desde esa perspectiva, se comprende que Menéndez Pelayo insistiera en la línea regalista, mientras el P. Miguélez señalara el aspecto moral, basado en la condenación de la Inquisición, dominada por los jesuitas, de la obra de cardenal Noris (1748). Y por la línea de Miguélez se inclinan dos historiadores extranjeros de mediados del siglo Xx, el francés Sarrailh y el norteamericano Herr ${ }^{33}$.

Pero ¿qué pensaban del jansenismo los hombres del Xviri? Me valgo de unas palabras del inquisidor de Valladolid, Andrés Ignacio Orbe, sobrino del Inquisidor General, en carta a su amigo y maestro G. Mayans:

Por tener la séptima parte de Van Espen, he comprado dos veces sus obras, y nunca he podido comprar la séptima, sus Comentarios a Graciano, aunque breves, no pueden dejar de ser excelentes, si corresponden a lo demás de sus obras. Sus Opúsculos, o cuarta parte, es cosa buena, lo que tiene contra el Augustino convincente; no le tengo yo por jansenista, esto es, sequaz de las 5 proposiciones, en lo demás que hoy llaman jansenistas algo tiene, pero como esto está declarado por Breve que a nadie se le llame, nada le perjudica. Aun al célebre Tomasino le dan este nombre ${ }^{34}$.

¿Y qué entendían por eso que «ahora llaman jansenismo»? A lo largo de la correspondencia de Andrés I. Orbe, puede deducirse el conjunto de actitudes que, a su juicio, se consideraban jansenismo:

La calificación de jansenistas se aplicaba, en primer lugar, a los que, defendiendo los derechos episcopales, se declaraban conciliaristas, negaban la in-

33 Marcelino Menéndez Pelayo, Historia de los heterodoxos españoles, vol. VI, Madrid, Victoriano Suárez, 1931; Manuel F. Miguélez, Jansenismo y regalismo en España. Datos para la historia. Cartas a. Sr. Menéndez Pelayo, Valladolid, Imprenta, Librería y Taller de Grabados de Luis N. de Gaviria, 1895; Jean SARRAILH, La España ilustrada de la segunda mitad del siglo XVIII, México D. F. / Buenos Aires, Fondo de Cultura Económica, 1957; Richard Herr, España y la Revolución del siglo XVIII, Jerez de la Frontera, Aguilar, 1964.

34 A. I. Orbe a G. Mayans, 28-XII-1746, en MaYans y SISCAR, Epistolario XXII. Los hermanos Mayans. 
falibilidad del Papa, limitaban el centralismo disciplinar de Roma o reducían la potestad eclesiástica al campo espiritual. Por otra parte, se calificaba también de jansenistas a los que estudiaban la disciplina antigua, defendían una moral rigurosa o se oponían a los jesuitas ${ }^{35}$.

Conviene tener presente este criterio de Andrés I. Orbe para entender la evolución del jansenismo español del XVIII. Porque, dado el interés europeo por el siglo de la Ilustración, y los crecientes estudios sobre el XVIII español, la sociología religiosa de la centuria ha adquirido una revisión de criterios sobre el jansenismo. L. Ceyssens, desde Holanda, llamó la atención sobre la diferencia entre el jansenismo doctrinal y el jansenismo histórico — como Orbe decía: «lo que hoy llaman jansenismo»—. Esa distinción ayuda a entender las acusaciones de jansenista a muchos escritores que no defendían las 5 proposiciones, y que originaban polémicas escolásticas y de partido. Por su parte, el historiador francés Émile Appolis publicó en 1960 Entre zelanti et jansenistes: le «Tiers Parti» catholique. Y, como no había incluido en su estudio el caso español, publicaba años después Les jansenistes espagnoles (1966), que consideraba el Tercer Partido en España. Ese interés de los historiadores galos por el jansenismo español del XVIII ha tenido herederos. J. Saugnieux ha estudiado la influencia francesa en los obispos españoles (caso de José Climent) y la importancia de estos prelados en la reforma de la oratoria sagrada, y Paula Demerson ha insistido en la influencia de la Constitución Civil del Clero en el grupo jansenista de la Corte.

Similar interés han demostrado los historiadores italianos por el jansenismo. Jemolo, Codignola, Dammig han analizado, desde la actividad docente de los agustinos (Berti) a las actitudes rigoristas, sin olvidar las posturas políticas. Y, sobre todo, la importancia del Sínodo de Pistoia (el obispo Ricci o el teólogo Tamburini), con todas las implicaciones políticas, religiosas, tanto en el campo eclesiástico (curia, conciliarismo) como espirituales. No pueden olvidarse las repercusiones en el mundo cercano a la Curia Romana con personajes como Bottari, Passionei o Foggini. Además de que la prensa española se hacía eco de manera especial de los acontecimientos italianos, Tomsich ha estudiado la influencia del sínodo entre los intelectuales españoles. Asimismo, C. Mas ha señalado el caso especial de la influencia en el Seminario diocesano de san Fulgencio de Murcia, gracias a las reformas del obispo Rubín de Celis.

Tanto interés parece demostrar el jansenismo español del xvIII que el juicio de Villapadierna no era muy exacto: «En vano se buscará su reseña o su men-

35 Mestre SAnchis, «Religión y cultura en el siglo XVIII español», pág. 646. Para las siguientes aportaciones de los historiadores recientes sobre el jansenismo (y citas) véase este capítulo, págs. 583-743. 
ción en las historias y monografías del movimiento jansenista español». Claro que este juicio fue escrito en 1954. Pero, además, Villapadierna consideraba el movimiento en España, clerical y tardío: «Teniendo en cuenta que el jansenismo entrañaba un problema religioso (la reforma de la iglesia) que interesaba particularmente al clero, la existencia de un partido clerical que propugnara la reversión a la antigua disciplina no se hizo patente hasta el último decenio del siglo XVIII» ${ }^{36}$.

Aceptado el criterio de que en la última década del siglo XVIII se dio con la mayor fuerza el jansenismo español, conviene ver las circunstancias que condujeron a esa eclosión. Y el texto antes citado de Andrés I. Orbe nos puede servir de guía.

Episcopalismo. El 15 de enero de 1752, Mayans escribía a Burriel. Después de defender su Examen del concordato del 1737, añadía estas palabras:

El principal fin fue moderar la codicia de los Curiales Romanos y librar al estado eclesiástico del gravamen que le había puesto el Concordato. Yo soy tan amante, o más, de los obispos que V. Rma.; soy de sentir que los Papas y reyes los han oprimido, que esta opresión no se puede quitar arrimándose a los Papas, y que es menester favorecer a los reyes tomando este pretexto para favorecer a los obispos. El favor le entiendo según los cánones.

Al margen de que los años convencieron a Mayans de que los reyes tampoco favorecían la libertad de los obispos, el erudito veía en los cánones la autoridad que los obispos adquirían por la consagración, iure divino, y la jurisdicción sobre su diócesis, incluidos los monjes y religiosos, y el derecho de convocar concilios. Y, remitiéndose a la historia, recordaba que los concilios de Toledo, en tiempo de los visigodos, habían sido el instrumento de reforma eclesiástica. Así, deseaba que la celebración en su tiempo constituyera un estímulo para la reforma personal del clero y de los fieles. Claro que la celebración de concilios diocesanos, provinciales o nacionales, no era bien vista, ni por Roma, que temía el aumento de iglesias nacionales, ni del gobierno, que no deseaba que los obispos adquirieran conciencia de su misión y poder. Así quedó patente, porque solo dos concilios lograron celebrarse en el xvIII. Uno en México, con la presidencia del futuro cardenal Lorenzana, que no tuvo aplicación, y otro en Manila con la participación del escolapio e historiador Traggia, que no llegó a ver la luz pública.

\footnotetext{
36 Isidoro de Villapadierna, «El jansenismo español y las Cortes de Cádiz», en VV. AA., Nuove Ricerche sul giansenismo, Roma, Pontificiae Universitatis Gregorianae, 1954, págs. 273-303.
} 
Y, por parte de los obispos españoles, es menester confesar la general subordinación al gobierno que los había elegido. Hubo excepciones y, por cierto, el gobierno no los trató con mucha benignidad. Así, el obispo de Cuenca fue sometido a un sonado proceso, aunque el caso de José Climent, obispo de Barcelona, tuvo mayor relieve. Climent tenía conciencia de su dignidad de obispo. Nombrado para la sede de Barcelona, no quiso visitar a Carlos III, como era costumbre de que el electo visitara al monarca. Y, después de recibir al jansenista francés Clement, escribió una carta al Papa para que, como símbolo de la unidad de la Iglesia, perdonara a la Iglesia cismática de Utrecht. Roma recibió con disgusto la carta de Climent e indicó al monarca que censurase al obispo de Barcelona. Pero Carlos III, aconsejado por Roda, no estaba dispuesto a ceder a las presiones de Roma. Convocó una comisión de obispos, que confirmaron la ortodoxia de Climent. No acabó ahí la actitud como fruto de su conciencia de obispo. Con motivo de las quintas, Climent defendió los gremios frente al criterio de Campomanes. Y en este caso Carlos III no tuvo contemplaciones con el obispo. No se atrevió a destituirlo, ni tenía poder para hacerlo, pero le exigió su traslado a la sede de Málaga. Y Climent, que consideraba el obispado vinculado a su diócesis, rechazó el nombramiento, y se retiró a su casa. El obispo, como decía años antes Mayans, estaba entre dos autoridades que lo sojuzgaban: el papado y la monarquía ${ }^{37}$.

Toda esta efervescencia de la reivindicación de los derechos episcopales con influencia jansenista adquirió fuerza durante la última década del siglo. Hubo un cambio generacional en la política: muerte de Carlos III, Floridablanca y Campomanes perdieron poder y el conde de Aranda constituyó el puente para el gobierno de Godoy, que se vio obligado a firmar la paz de Basilea con los revolucionarios franceses (1795). Pero también se produjo un cambio generacional en los obispos. Fallecidos Bertrán y Climent, adquieren fuerza y poder otros prelados: Tavira, «el corifeo del jansenismo» según Menéndez Pelayo, los hermanos Abad y Lasierra, Agustín obispo de Barbastro y corresponsal de Gregoire, y Manuel, Inquisidor General; Antonio Palafox, obispo de Cuenca y familiar de la condesa de Montijo; o Francisco Mateo de Aguiriano, defensor del Decreto de Urquijo.

Por lo demás, un grupo de clérigos, jansenistas mucho más radicales, residían en la Corte. Eran, en el fondo, la nueva generación salida de las Universidades reformadas después de la expulsión de los jesuitas: Juan Antonio Llo-

37 Climent ha merecido estudios recientes: Tort, Adell, Lledó, C. Vázquez... El caso concreto de la diócesis de Utrecht y la carta al Papa, en Antonio Mestre SAnchis, «La influencia de van Espen en la España del siglo XVIII", Revista de Historia Moderna. Anales de la Universidad de Alicante, 19 (2001), págs. 405-430. El texto fue presentado al coloquio organizado en Lovaina con motivo de III centenario del libro clásico de Van Espen y publicado en francés en G. Cooman, M. van Stiphout y B. Vauters (eds.), Zeger-Bernard van Espen at the crossroads of Canon Law, History, Theology and Church-State relations, Lovaina, Peeters, 2003, págs. 267-297. 
rente, Joaquín Lorenzo Villanueva, los canónigos de la Colegial de San Isidro, profesores de los Reales Estudios de San Isidro y agustinos de alto nivel intelectual, entre ellos el P. José La Canal. Por cierto, aunque los libros polémicos no eran de dominio popular, los hombres de letras interesados podían conocer el alcance y sentido del problema. En 1798 se publicaba en Madrid la traducción del libro de Rocco Bonola La liga de la teología moderna con la filosofía en daño de la Iglesia de Jesucristo. Era un duro ataque a la lectura de la Biblia en lengua vulgar, el episcopalismo y los principios del llamado jansenismo. Era precisa una respuesta rápida, y el P. Diego Fernández de Rojas publicó el folleto El pájaro en la liga (1798). La obra de Fernández de Rojas era una defensa fuerte, aunque irónica, del episcopalismo y de la convocatoria de concilios diocesanos o provinciales. Es decir: era una apología hábil del jansenismo. Y, entre estos jansenistas, estaba José Espiga, el redactor del decreto de Urquijo. Por lo demás, también en la Corte residía un grupo de seglares interesados en la reforma de la Iglesia. Sin afán de nombrarlos a todos, baste recordar la importancia de la personalidad de Jovellanos. Y, si queremos, el círculo de jansenistas en el entorno de la condesa de Montijo, que, siguiendo el consejo del obispo José Climent, había traducido la Instrucción cristiana sobre el sacramento del matrimonio y sobre las ceremonias con que la Iglesia le administraba (1774) del jansenista francés Le Tourneux. En el prólogo del mismo Climent, el obispo censuraba con dureza el probabilismo y exigía el amor, aun en el sacramento de la Penitencia, para conseguir el perdón. Eran puntos básicos del jansenismo.

Ahora bien, si en la Corte alcanzaba mayor fuerza el movimiento jansenista, también encontraba buena acogida en otras ciudades. En Murcia, por ejemplo, en el Seminario de San Fulgencio, con las reformas introducidas por el obispo Rubín de Celis. En Valencia, con la presencia del agustino Sidro Villaroig, cuya obra demuestra la resonancia del Sínodo de Pistoia. O en Cataluña con los discípulos de Climent, Felix Amat y sus sobrinos los Torres Amat.

Esta generación, heredera del movimiento interno español y de la reforma universitaria de Carlos III, recibió nuevo impulso por la influencia extranjera. Conviene señalar dos corrientes. En primer lugar, el Sínodo de Pistoia, convocado por el obispo Ricci, cuyas actas fueron distribuidas con generosidad en España. Y, sobre todo, está el hecho de que el gobierno español no aceptó la Bula Auctorem fidei de Pío VI (1795), que condenaba las conclusiones del Sínodo. En segundo lugar, la Constitución Civil del clero, proclamada por la Revolución Francesa, que, aunque menos difundida, también fue conocida entre los grupos cortesanos y hubo corresponsales con el obispo juramentado Gregoire.

Todas estas corrientes propiciaron la publicación del Decreto de Urquijo (1799), que atribuía a los obispos la potestad de conceder dispensas y apela- 
ciones que se hacían a Roma. El decreto fue calificado como cismático. Y, si este calificativo nació en Europa, fue muy bien acogido por Menéndez Pelayo y otros historiadores. Ahora bien, las investigaciones de Rafael Olaechea y Teófanes Egido han venido a colocar el problema en las circunstancias históricas concretas: la Iglesia Universal sin Papa, Roma ocupada por el ejército napoleónico, con pocas esperanzas de convocación de Cónclave para elegir al sucesor de Pío VI. En esa tesitura, los citados Olaechea y Egido llegan a indicar que se trataba de un «anticisma». Lo cierto es que, elegido Pío VII como Papa y destituido Urquijo, con el retorno de Godoy, se anuló el Decreto. Por el momento, las polémicas se apaciguaron. Pero había quedado de manifiesto la existencia de dos concepciones religiosas con diferentes criterios respecto a múltiples aspectos disciplinarios. Y, consecuencia lógica, estas discrepancias volvieron a surgir con mayor fuerza en las Cortes de Cádiz.

\section{¿Y la masonería?}

Es bien sabido que sobre la masonería se ha producido amplísima bibliografía. Y conviene confesar que en muchas ocasiones ha sido apasionada y, en consecuencia, tendenciosa. Es preciso prescindir de los orígenes mitológicos. $\mathrm{Y}$, frente a los gremios de constructores medievales, que mantenían secretos sus adelantos técnicos, con sus signos propios — de cuya existencia nadie duda-, son calificados por los historiadores como la masonería operativa. Muy distinta es la moderna, la masonería especulativa, que nace en Inglaterra en el siglo XVIII, promovida no por los constructores, sino por los protectores y favorecedores.

En 1717, cuatro logias de Londres, dirigidas por estos favorecedores, se unieron con fines culturales y sociales. Las constituciones de esta Logia aparecieron en Londres en 1723, bajo el nombre del autor-redactor, Anderson. Conviene señalar el alcance y finalidad de las constituciones de la llamada masonería británica: solidaridad, libertad (también religiosa) e igualdad. Y, en cuanto al aspecto religioso, precisa tener en cuenta su condena del ateismo y su criterio de unidad religiosa, la religión de todos (es decir, el cristianismo), punto de unión de todas las diferencias religiosas que atormentaban a la sociedad inglesa: anglicanos, presbiterianos, calvinistas, católicos, arminianos... Esto no quiere decir que no hubiera desviaciones posteriores ${ }^{38}$.

38 El mejor estudio sobre la masonería en el siglo xviII es el libro de José A. Ferrer BenimeLi, Masonería, Iglesia e Ilustración, Madrid, Fundación Universitaria Española, 1977, 3 vols. 
Esta logia pronto suscitó centros que imitaron su constitución y sus prácticas. En España, la primera logia se creó en Madrid en 1728, en casa del duque Wharton, y todos sus socios (en muy escaso número) eran británicos. Una segunda logia fue creada en Gibraltar y, como es lógico, también eran británicos todos los socios. Por lo demás, también surgieron numerosas logias en Europa: Francia, Holanda, Suiza, Imperio, Italia...

El gran misterio era el juramento de guardar silencio absoluto y radical sobre el contenido de sus reuniones y de la finalidad de sus ideas y proyectos. Este secretismo produjo evidente preocupación en los Estados y no tardaron en prohibir la presencia de logias masónicas. La primera en prohibirlas fue Holanda — país protestante, conviene observarlo - seguida de Ginebra (calvinista, por supuesto), Baden y Hamburgo en el Imperio, Francia...

Desde esa perspectiva hay que mirar la condena del Papa Clemente XII, en su Constitución Apostólica In eminenti (28-IV-1738). En ella no aparece herejía alguna como motivo de condena, sino las alteraciones políticas, producidas por las logias masónicas en los Estados y los efectos negativos que podían producir en los fieles. La Constitución Apostólica de Clemente XII fue aceptada en Francia, Italia (especialmente en Florencia donde había un foco notable), Imperio... En España fue aceptada por el Santo Oficio, cuyo Inquisidor General, el arzobispo Andrés Orbe, comunicó la bula pontificia a las inquisiciones provinciales para que exigieran su cumplimiento. Pero no hubo condena alguna de Felipe V, como algunos historiadores afirman.

No parece que las logias masónicas en España tuvieran gran actividad que alterara el orden político o eclesiástico. En el exhaustivo estudio de Ferrer Benimeli solo aparecen dos procesos inquisitoriales. Francisco Aurion de Roscobet, clérigo tonsurado que, procesado en 1744, fue desterrado de los reinos de España. Y, años después, un presbítero de Olías se presentó ante los inquisidores, confesando que, mientras estuvo en Italia, tuvo amistad con un criado, ayuda de cámara del marqués de la Ensenada. El criado le habló de las grandezas de París y, entre ellas, de la asamblea de los masones de la que formaban parte monsieur Bance y Antonio Rosellón. Realizadas las investigaciones y dado que no hubo confirmación en las acusaciones, el Santo Oficio decidió incluir en los decretos inquisitoriales la obligación de delatar a todos los herejes, incluyendo las «Juntas, Congregaciones y Hermandades de los Franc-Masons o Liberi Muratori», condenadas por la Bula de Clemente XII. Conviene prestar atención a dos datos que volverán a presentarse en esta exposición: la presencia de militares y su contaminación en Italia.

Por lo demás, no hay duda de la ignorancia generalizada sobre la realidad la masonería, pues ni siquiera los inquisidores tenían conocimiento exacto. Así, 
el 8 de junio de 1745, el inquisidor de Valladolid Andrés Ignacio Orbe escribía a su maestro y amigo Gregorio Mayans que había comprado un libro sobre los masones. Una pena que no indicara de qué libro o autor se trataba, porque la descripción que hace es realmente muy pobre: juramento, secreto, extrañas ceremonias, irreligiosidad... ${ }^{39}$. Y Mayans, que era hombre curioso, preguntó a su amigo, el jesuita Andrés Marcos Burriel, bien relacionado en la Corte, y recibió una respuesta muy clara: «De los francmasones no he podido averiguar cosa alguna particular. Si la supiera, la daré a Vmd.» (28-VI-1746) ${ }^{40}$.

Mucho mayor era la presencia y actividad de las logias en Italia. Esta efervescencia masónica en Nápoles parece que fue el móvil de la condena de Benedicto XIV en la Bula Proveas, del 18 de mayo de 1751. Su contenido era la excomunión de todos los que formaban parte de las logias masónicas, confirmando la condena de Clemente XII. Y, esta vez, con el informe - duro y contundente- del Confesor, el jesuita Francisco Rávago, Fernando VI prohibió las logias masónicas, y entre las penas está la destitución de los funcionarios, no la pena de muerte, como algunos historiadores afirman. En consecuencia, el Santo Oficio se vio obligado a vigilar y controlar cualquier asomo de masonería.

Tres actitudes se hicieron visibles ante la prohibición del monarca y la condena inquisitorial. Dado que se concedía el perdón a quienes se presentaran voluntariamente ante el Santo Oficio, hubo dos masones que se delataron: uno en la Corte, Ignacio Le Roy, y otro en Oliva, por medio de Gregorio Mayans ${ }^{41}$. En este caso Guillermo Clauwes de Chambrun, militar extranjero en el ejército de Fernando VI, y residente en Denia, se presentó en casa del erudito y Mayans realizó los trámites para que el militar pudiera renunciar a la masonería ante el párroco de san Roque de Oliva y fuera reconciliado por el Santo Oficio. Pero un dato reviste importancia: ante la solicitud de que confesara los nombres de sus compañeros en la logia, dio una lista de nombres, todos ellos militares y extranjeros, e incorporados a las logias mientras estaban en el ejército español de Italia ${ }^{42}$.

Una segunda actitud consistió en combatir la masonería por medio de obras literarias. La primera y más disparatada fue la del P. Torrubia: Centinela contra

\footnotetext{
39 ¿Podría tratarse de Larudan, LOOrdre des Francs-Maçons trahi et le secret des Mopses révelé [...], Ámsterdam, 1745?

40 Los textos de ambas cartas en Gregorio Mayans y Siscar, Epistolario II. Mayans y Burriel, ed. de Antonio Mestre Sanchis, Valencia, Ayuntamiento de Oliva, 1972; y Epistolario XX. Los hermanos Mayans y los Inquisidores, ed. de Amparo Alemany Peiró, Valencia, Ayuntamiento de Oliva, 2003.

${ }^{41}$ El caso de Clauwes de Chambrum se descubrió entre los papeles de Mayans, lo que puede verse en Antonio Mestre SAnchis, «Un masón reconciliado en casa del erudito Mayans y Siscar», Antológica annua, 18 (1971), págs. 685-718.

42 La lista de masones, citados en Ferrer Benimeli, Masonería, Iglesia e Ilustración, vol. II, págs, 89-90.
} 
francmasones (1752). Exagerada y muy inexacta diatriba contra una supuesta masonería. Mucho más equilibrada y, en cierto modo, una respuesta a la obra de Torrubia, fue una de las cartas eruditas del P. Feijoo (CE, IV, 16). Aunque manifiesta la ignorancia general sobre la masonería, demuestra prudencia ante la ignorancia de la realidad. Y una tercera en latín, y en consecuencia destinada a los profesores, de Fr. Juan de la Madre de Dios: Adumbratio Liberorum Muratorum (1751).

Finalmente, la actitud que conocemos por los testimonios conservados en los archivos inquisitoriales. En este caso, son las ciudades andaluzas, especialmente Cádiz, por la presencia de extranjeros, las que señalan la existencia de algunas personas acusadas de pertenecer a logias masónicas, sin mayor trascendencia.

El reinado de Carlos III ha sido considerado como la etapa de difusión de la masonería en España. Si el monarca ha quedado libre de esa acusación, por sus testimonios personales contra las logias en su correspondencia con Benedicto XIV, siendo rey de Nápoles, y con Tanucci, la acusación continúa sobre sus ministros, especialmente el conde de Aranda. La figura del aristócrata aragonés ha ido acompañada de la leyenda: principal artífice de la expulsión de los jesuitas, volteriano y Gran Maestre de la logia masónica de Madrid. Rafael Olaechea y Ferrer Benimeli ya demostraron, en su conocido estudio sobre Aranda, que la planificación del exilio de la Compañía fue obra de Manuel de Roda y del Fiscal Campomanes. Aranda, como militar, fue el encargado de realizar la operación concreta de la expulsión. Por lo demás, continúa la leyenda de Aranda fautor de la masonería y creador de la Gran Logia de Madrid. La proposición, aunque no se atrevió a firmarla, tuvo su origen en Vicente de la Fuente, Historia de las sociedades secretas en España (1874), y otros la han mantenido. Sin embargo, Ferrer Benimeli ha demostrado con razones potísimas la imposibilidad de que Aranda crease la logia de Madrid, pues en las diferentes fechas (ni en eso coinciden) el aristócrata aragonés estaba como embajador en Paris.

Pero hubo masones en la España de Carlos III. Quedó constatada en los casos descubiertos en Nápoles la existencia de logias en puertos de mar, especialmente en Cádiz. Y, ante la indicación del monarca, el Santo Oficio encargó al tribunal de Sevilla inquiriese la realidad. Los inquisidores del tribunal de Cádiz detectaron la existencia de papeles masónicos en dos personajes extranjeros: un protestante francés, Michel Perron, y el vicecónsul ruso, Jorge Vreling (17761777). Ambos habían ya fallecido. Los papeles fueron recogidos, pero, ante las protestas de los embajadores de sus respectivas naciones ante Floridablanca, los papeles fueron devueltos a sus familias ${ }^{43}$. Por lo demás, no hay duda de que

\footnotetext{
43 Ferrer Benimeli, Masonería, Iglesia e Ilustración, vol. III, pág. 276-278.
} 
existían logias masónicas en Gibraltar, ocupada por los ingleses después de la guerra de Sucesión, como también en Menorca durante los años que estuvo bajo el dominio de la Gan Bretaña. Asimismo, hubo españoles en las logias de París, censados como visitantes y Ferrer Benimeli da su identidad: dos maestros de la logia de San Pedro de Oriente de Villanueva (5-IV-1787) y Pedro de Córdoba de la logia de Madrid (1788).

La Revolución Francesa modificó la interpretación de la masonería. Al estudiar los orígenes del movimiento revolucionario, historiadores como el francés Barruel o el español Hervás y Panduro incluyeron a la masonería entre sus causas ${ }^{44}$. Pero este problema no existió en España. Sí hubo, por supuesto, alguna logia. G. Demerson demostró en un artículo, publicado en Bulletín Hispanique (1955) y basado en las actas, la existencia de una logia masónica en Brest (1799-1801), erigida y mantenida por los marinos españoles, mientras la armada hispano-francesa estuvo anclada en el puerto ${ }^{45}$. Si bien, su finalidad primera era la solidaridad y filantropía entre sus miembros, y sin intencionalidad antirreligiosa, hasta el extremo de la presencia de 5 sacerdotes católicos entre los socios de la logia.

De hecho, los historiadores modernos mejor documentados (H. Kamen, en su estudio sobre la Inquisición, R. Herr, José A. Ferrer Benimeli) niegan una numerosa existencia de logias masónicas en la España del siglo XVIII. Del mismo criterio era el Consejero de Estado y Prefecto de la Policía de París, en un informe de 1824 al Ministro del Interior francés. El Prefecto de Policía señalaba que la masonería era desconocida en España hasta la invasión napoleónica y que adquirió fuerza y vigor en las Cortes de Cádiz. Y, si al principio los masones se centraban en asuntos filantrópicos, a partir de 1814 aumentaron y los masones entraban en todas las conspiraciones políticas ${ }^{46}$. Al margen de la apreciación parcial de un político francés conservador, su criterio coincide con el juicio de los historiadores mejor informados.

Es decir, tanto desde la perspectiva eclesiástico-religiosa, mirada desde el jansenismo-conciliarista, como desde el punto de vista político, las líneas fundamentales cristalizaron en las Cortes de Cádiz.

$44 \quad$ El alcance de las teorías del abate Barruel y del jesuita Hervás y Panduro, dentro de las interpretaciones del origen de la Revolución Francesa, en FERrer Benimeli, Masonería, Iglesia e Ilustración.

45 Georges Demerson, «Une loge maconnique espagnole a Brest (1799-1802)», Bulletin Hispanique, LVII (1955), págs. 375-400.

46 Ferrer Benimeli, Masonería, Iglesia e Ilustración, vol. III, pág. 557. 